This item was submitted to Loughborough's Research Repository by the author.

Items in Figshare are protected by copyright, with all rights reserved, unless otherwise indicated.

\title{
Immigration and the British news media: Continuity or change?
}

PLEASE CITE THE PUBLISHED VERSION

https://doi.org/10.1111/soc4.12618

PUBLISHER

() John Wiley \& Sons Ltd.

\section{VERSION}

AM (Accepted Manuscript)

\section{PUBLISHER STATEMENT}

This is the peer reviewed version of the following article: SMITH, D. and DEACON, D., 2018. Immigration and the British news media: Continuity or change? Sociology Compass, 12 (9), e12618, which has been published in final form at https://doi.org/10.1111/soc4.12618. This article may be used for non-commercial purposes in accordance with Wiley Terms and Conditions for Use of Self-Archived Versions.

\section{LICENCE}

CC BY-NC-ND 4.0

\section{REPOSITORY RECORD}

Smith, David, and David Deacon. 2018. "Immigration and the British News Media: Continuity or Change?". figshare. https://hdl.handle.net/2134/33923. 


\title{
Immigration and the British News Media: Continuity or Change?
}

David Smith

David Deacon

\begin{abstract}
This article examines research carried out over the last 40 years in the area of media and migration in the British context. This thematic review of more than sixty empirical studies explores how UK media attention to the immigration issue has fluctuated over time, but has displayed consistent negativity in its terms of reference, exclusionary features and significant interpretative limitations, not least in the conflation of distinct types of migration.
\end{abstract}

Keywords: immigration, media, migration, news media.

\section{Introduction}

In the two years leading up to the historic 2016 EU referendum in the United Kingdom, British citizens were more consistently concerned about immigration than about any other issue (Blinder \& Allen, 2016). Polling suggests that the public overestimates levels of immigration, a misperception also found in other countries (Ipsos MORI, 2014). The majority of UK people see immigration in negative terms and are far more worried about recent trends towards positive net migration than other European neighbours (Vlandas, 2016), even though these levels are not remarkable in comparative terms (Semmelroggen, 2016). While worldwide trends suggest that more people would like to see immigration remain at present levels or increase than decrease, 7 in 10 people in the UK would like immigration to be reduced (Esipova et al., 2017). This is reflected in a print media characterised by the hostility of some of the country's most well-circulated newspapers, even when 
compared to other developed countries of reception (Berry et al., 2015; Chouliaraki et al., 2017; McAuliffe et al., 2017). Ultimately, the strength of British public antipathy to immigration to the UK played a central role in Leave voters' decision to 'Brexit' in 2016 (Goodwin \& Milazzo, 2017).

The British public are constantly being told stories about immigration. These stories add up to a complex range of narratives and counter narratives that are mobilised in the public arena by politicians, populist insurgents, journalists, campaign groups and commercial interests. These competitive and often contradictory narratives provide explanations about the meaning of macro-processes that are well beyond the personal experience of individual citizens. In the creation of this public conversation, the mainstream news media have always played a very significant role. Moreover, they are not neutral agents in the construction of this debate, being governed by their own institutional and ideological imperatives. Indeed, research conducted by Ipsos MORI on attitudes to immigration in the UK found that the choice of which newspaper one reads is one of the most important predictors of attitudes towards immigration, a correlation not found for attitudes towards other issues (Duffy, 2014; see also Blinder, 2015). Any analysis of the formation of public understanding and attitudes in this area therefore needs to attend to features and fluctuations in media discourse (McLaren et al., 2017).

There is, of course, a high degree of variability in the mode, range and reach of media institutions and their output. Scholars are increasingly having to consider the complexities of research design when dealing with the more atomized, personalised and interactive consumption logics of new media platforms. Nevertheless, the content of so-called 'legacy media' institutions remains central to most people's everyday lives. The BBC, for instance, claims to reach a weekly audience of $372 \mathrm{~m}$ people around the world across its various platforms (BBC, 2017). Lists of the most visited news websites around the world tend to be dominated by organisations with an 'offline' presence, which can afford to invest (often at a loss) in a web counterpart to their print version. Given the scale of this influence, it is perhaps unsurprising that much of the prevailing research in the area of media and migration tends to focus on the content and impact of the mass media, such as newspapers and TV news. 
This article collates research evidence related to legacy news media coverage of immigration in the United Kingdom. This specific spatial focus is not intended to imply any special significance to this national context nor to the quality of the research conducted within it. We are mindful that the specific geographic dimensions of migration histories and their corresponding public discourses prevent us from making confident generalisations. Nevertheless, given the obvious connections that can be drawn between public negativity, a partisan print media and the seismic nature of the recent Brexit vote, it is an opportune moment to consider how the issue has been mediated both historically and more recently. The significant body of research which has developed in this regard in the UK is facilitative of such an enquiry. In this review, we therefore provide an overview of the history of research in this area and the major themes which have marked news media coverage of immigration in the UK. We conclude by briefly assessing the extent to which these themes are entrenched versus the degree to which we can identify any countervailing tendencies, before concluding by considering the implications of the review for further research.

\section{The history of the research area}

Serious academic interest in Britain into the mediation of immigration issues emerged in earnest in the 1970s, viewed initially through the prism of 'race relations' and racism (e.g. Bagley, 1973; Critcher et al., 1977; Hall et al., 1978; Hartmann \& Husband, 1974; Hartmann et al., 1974). This was principally in response to the politicisation and racialisation of the immigration issue, beginning in the late 1950s, as black and Asian migrants arrived from the New Commonwealth countries. The hostile and prejudicial reception these migrants received was in stark contrast to the relatively unproblematic reception given to white immigrant groups (e.g. those from Australia, South Africa, Canada, and Ireland). In the public debate around the issue, immigration and 'race' were effectively synonymous (Kilvington \& Saeed, 2014).

Racism and the Mass Media (Hartmann \& Husband, 1974), a landmark study that emerged from this period, still constitutes an essential source for scholars wishing to understand the politics of immigration during this time, and the place of media representation within this. Hartmann and Husband's study used both survey analysis and a content analysis of four national newspapers between 1963 and 1970 
in order to explore the role of the media in the formation of white Britons' perceptions and attitudes towards non-white people. Coverage of 'race' issues increased markedly over their sample period, during which time immigration was the most frequent 'race'-related topic. Importantly, the authors suggest that this coverage was 'not simply about coloured [sic] people coming to settle in the country' but 'had as a central theme the question of keeping them out' (p. 136). Britain's non-white population had been represented as 'some kind of aberration, a problem, or just an oddity, rather than as 'belonging' to the society' (p. 145).

Another study from this period also had a lasting influence on the field, while additionally demonstrating a good deal of prescience in anticipating the direction in which media and political debate was heading. Policing the Crisis (Hall et al., 1978) presaged a number of studies in/of the 1980s which explored the way in which Britain's black population came to be increasingly criminalised and the immigration issue continued to be problematised through this period (e.g. Gordon \& Rosenberg, 1989; Searle, 1989; Troyna, 1981; van Dijk, 1991). This period was also notable for a growing awareness that racist discourse was increasingly being defined by cultural definitions more than biological ones (Barker, 1981), and a later appreciation of a longer-term trajectory towards the 'discursive deracialisation' of immigration discourse (Augoustinos \& Every, 2007; see also Hall, 1990), requiring more nuanced and sensitive analysis in more recent periods.

The following sections will explore the most common themes identified in the scholarship of this area, namely the prominence of the issue, its negativity, its narrowness, the marginalisation of migrant sources and the conflation of migration categories in coverage. While these do not exhaust the range of features that can be found within immigration discourses, they consistently recur across a variety of studies and thus bear important consequences for the wider politics of the issue.

\section{Prominence}

Studies of news media debate over the past couple of decades suggest that immigration has risen in salience in the public debate and has become increasingly politicised. In the case of general election coverage, for instance, Smith (2015) charted the emergence of the issue in campaigns between 1918 and 2010, finding that the issue was rarely the subject of sustained attention in campaigns until the 
1970 general election. However, it thereafter failed to surface again as a particularly notable electoral issue until the 2000s. In relation to these latter campaigns, a recent study by Deacon and Smith (2017) found that immigration coverage rose substantially between the 1997 and 2005 campaigns, constituting roughly 1 per cent of all electoral coverage in the 1997 election campaign, surpassing 3 per cent in 2001 but reaching almost 10 per cent in the 2005 and 2010 elections. The authors attribute this rise in coverage to "increases in levels of immigration, asylum applications, policy initiatives and public attentiveness to the issue" (p. 17), in addition to the electoral strategy of the Conservative Party.

Analysis of the level of immigration coverage in more 'typical' periods of public life than election campaigns reveals similar, if not more emphatic, degrees of rising and sustained salience. Gabrielatos and Baker found a 'clear, upward trend' (2008, p. 17) in the amount of coverage of immigration between 1996 and 2005. Wars, disasters and terrorist attacks were key to these spikes, but domestic political events and debates also featured as contributory factors. Similarly, an analysis of claims made by political figures in the Guardian and the Daily Mail between 1995 and 2009 suggested that the salience of immigration grew steadily throughout the latter half of the 1990s and through the first half of the 2000s (Carvalho et al., 2015), while Picard (2014) recorded a 500 per cent increase in the number of national newspaper stories about immigration between 2000 and 2007. A relative decline in the salience of the immigration issue thereafter corresponded with the rise and fall of the issue in opinion polls during the 2000s (owing largely to the sudden dominance of the global financial crash on the political/public agenda).

Studies of immigration coverage in the 2010s suggest, however, that overall upward trends have since resumed. Allen (2016), for instance, found a 'sharp increase' in the volume of coverage from 2010, while Gerard (2017) notes that the British national press produced 277 front pages about immigration in 2016 - half of which were published by the right-of-centre mid-market tabloids, the Daily Express and Daily Mail. A relative drop in coverage in the 2015 general election campaign compared with prior campaigns is explained in terms of issue ownership and electoral strategy on the part of the main political parties, more than a disengaged media (Deacon \& Smith, 2017). 
Much of the recent coverage appears to be driven by attention towards migration into Europe and intra-EU migration (Balch \& Balabanova, 2016; Allen, 2016). The 'migration crisis', for instance, which gained salience in European Union countries during 2014 and 2015, had a notable impact on UK coverage (Berry et al., 2015; Chouliaraki et al., 2017).

\section{Negativity}

Despite a desire voiced by some to move analysis beyond a binary positive-negative paradigm (e.g. Benson 2014, Balch \& Balabanova, 2016), examinations of the negative representation of migrants, including discussions of prejudice, hostility and problem/threat-framing, are endemic in academic studies of the news coverage of migration, and have been since early studies (Bagley, 1973; Hartmann \& Husband, 1974; Hartmann et al., 1974; Hall et al., 1978; Troyna, 1981; Gordon \& Rosenberg, 1989; Searle, 1989). This has continued to be observed in the most recent of analyses; Berry et al.'s analysis of European coverage of the migration/refugee crisis suggested that the UK's coverage was overall 'the most negative, and the most polarised', with the country's right-wing media in particular demonstrating a unique degree of aggression and hostility (2015, p. 1). Some scholars, particularly those from a critical discourse studies approach, have even formulated a term 'negativisation' - to summarise the process(es) involved in these representational patterns (van Dijk, 1989, 1991; Khosravinik, 2009; see also Bennett et al., 2013). Others have conceptualised them in terms of deviance and moral panic (e.g. Banks, 2012; Berkeley et al., 2006; Gabrielatos \& Baker, 2008; Khosravinik, 2014; Hall et al., 1978; Khan, 2012), crisis (e.g. Hall et al., 1978; Berry et al., 2012), othering (e.g. Bailey \& Harindranath, 2005), threat (e.g. Mollard, 2001; Gross et al., 2007; Khosravinik, 2009; Innes, 2010; Philo et al., 2013a), and racism/racialization/xenophobia (e.g. Hartmann \& Husband, 1974; van Dijk, 1991; Bailey \& Harindranath, 2005; Fox et al., 2012).

Overall, negativity is seen as providing a framework for understanding many of the features of news coverage of immigration, including those discussed in other respects below, such as the themes of coverage and quotation patterns. For instance, in the case of themes, although the emphasis in the discussion below is on their 'narrowness', another key attribute of the themes identified in coverage is that 
they are inflected by negativity. As van Dijk suggests, for example, 'even potentially 'neutral' topics...soon tend to have a negative dimension' once thematised in terms of threats, problems, etc (2000, p. 38). Van Dijk's conceptualisation of what he calls the 'ideological square' is seen as applying across discourse, and therefore also in the selection of topics: 'what we find is a preference for those topics that emphasize Their bad actions and Our good ones' (ibid.). Those which would place a focus on the in-group's ('our') bad actions and 'their' good ones are rarely thematised.

In terms of the framing of migration, recent analysis by Balch and Balabanova suggests that 'communitarian' (i.e. broadly anti-immigration) frames dominated over 'cosmopolitan' (i.e. broadly pro-immigration) frames in their 2006 and 2013 news sample, and that this increased from approximately three in every four frames in 2006 to over nine in every ten by 2013 (2016). Of these communitarian frames, 'domestic social justice' (comprised of 'welfare chauvinism' and 'economic nationalism') was by far the most prevalent frame overall. Accordingly, Buonfino (2004) and Caviedes (2015) have found that 'securitization' and 'economization' discourses respectively have been ascendant in the public debate. As these findings suggest, the question of migration is often posed in terms of security or the economy, and migration is seen as conditional on the costs and benefits associated with these aspects. As for frames of migrants themselves, Crawley et al. (2016) and Benson (2014, in the French/US context), use a tripartite frame typology that assesses the framing of migrants as 'heroes', 'villains'/'threats', or 'victims'. They find that, though hero frames are marginalised (e.g. 10\% in Crawley et al, 2016), villain/threat frames are not necessarily entirely dominant; the relatively high prominence of victim frames (38\% in ibid.) complicates the usual positive/negative framework. While Benson (2014) suggests that victim frames can be seen as ultimately sympathetic, others suggest that they often position migrants as passive and needy, and ignore the more rounded and ordinary experiences migrants have in their daily lives (Crawley et al., 2016; Khan, 2012).

The language used in migration coverage offers further clues as to the negative angle taken by many outlets on the issue. Studies in corpus linguistics (analysing consistent patterns in newspaper language, with samples of millions of words) have provided a number of relevant findings. For instance, Romanian immigrants are connected linguistically with crime (Vicol \& Allen, 2014), 'illegal' and 
'failed' are frequent modifiers of 'immigrant' and 'asylum seeker' respectively (Blinder \& Allen, 2015), use of terminology relating to the scale and pace of immigration is common and has risen (Baker \& McEnery, 2005; Allen, 2016), and negative metaphors provide important interpretive detail in the language of news reports. Indeed, metaphoric terms related to pejorative water-based disasters such as 'pour', 'flood', 'stream' and 'waves' have been identified in a number of studies (Baker \& McEnery, 2005; Baker et al., 2008; Buchanan et al., 2003; Charteris-Black, 2006; McLaughlin, 1999; Mollard, 2001; Musolff, 2015).

\section{Narrow debate and recurrent concerns}

Numerous recent studies have noted how constricted the parameters of news discourse tend to be when discussing immigration and 'race' (Bailey \& Harindranath, 2005; Baker et al., 2008; Law, 2010; Threadgold, 2009; van Dijk, 2000, 2012). Van

Dijk summarises 'ethnic news' as being about a handful of key issues: the construction of non-European immigration as a 'major problem'; problems of reception, housing, employment and integration; crime and violence (including 'illegal' immigration); and party political disputes (2012, 2000). Absent from this discussion, he argues, are issues such as various problems that migrants have in a new social and cultural environment and their experiences with exclusion, marginalization and problematization (2012).

Such limited concerns seem to be an enduring feature of news reporting of immigration in the UK. Comparing reporting patterns in the 1970s and 2000s, Berkeley et al. (2000) found that 'much of the negative tone and frameworks of discussion' have remained the same (p. 25) and that media discussion continues to be conducted 'within the framework of immigration control, assisted by an unrelenting staple of panics about mass influxes, criminal behaviour, welfare state crises and illiberal cultural difference' (ibid.). An even more extensive temporal perspective is provided by Smith's (2015) comparison of election news between 1918 and 2010, which found that issues relating to immigration control, crime, forced migration (i.e. asylum seekers and refugees), 'numbers' and the electoral mobilization of ethnic minority groups were the most common themes over this time period. Even as immigration related issues gained salience over the latter stages of 
the sample, there was an appreciable constriction in the plurality of the debate (Smith, 2015).

The research evidence also suggests that there is very little internal diversity within and between media sectors in their coverage of immigration issues. A key finding from Hartmann and Husband's analysis coverage in the 1970s was the narrowness and consonance in the subject matter of the different newspapers sampled. Quality and popular newspapers may have framed their coverage differently but they were 'in close agreement about what the issues [were]' (1974, p. 133). The evidence also suggests that British public broadcasters have followed similar lines to the newspapers in their reporting. Gross et al. (2007) found that, while broadcast news programmes don't necessarily cover all of the immigration stories published in the print media, they do tend to only cover those that have already appeared in print.

\section{Marginalisation of migrant voices and sources}

Regarding the politics of media access in the formation of migration coverage, numerous studies show that official sources and those from powerful institutions tend to dominate (e.g. Hall et al., 1978; Threadgold, 2009; van Dijk, 1991; Buchanan et al., 2003; Smith, 2015; Wahl-Jorgensen et al., 2013). In Jacomella's view (2010, p. 92), elite perspectives dominate and 'direct public discourses, until they become "common sense"'. According to Hall et al. (1978), it is this power of 'primary definition' that permits the institutionally powerful to establish a pre-eminent interpretation of the issue, setting the terms of reference upon which all subsequent debate takes place. Less established sources may take issue with the way in which the (narrow range of) themes are framed, but in doing so they implicitly concede that these are what the debate is 'essentially about' (p. 59).

A further indicator of this elite-dominated debate is the relative absence of the voices and perspectives of migrants themselves. Studies generally suggest that migrant voices comprise between $8 \%$ and $17 \%$ of sources in news (usually press) coverage of immigration. Refugees were the main source in $8 \%$ of press reports in Buchanan et al.'s study (2003), while Migrant Voice (2014) found that migrant sources comprised $12 \%$ of sources in their 2014 study. Crawley et al. (2016), in their frame analysis of immigration coverage prior to the 2015 general election, found that 
$15 \%$ of this coverage featured migrants as sources. Smith (2015) found that migrants comprised almost $17 \%$ of all sources in his longitudinal analysis of election coverage, although migrants' 'news access' (i.e. quotation) was lower in every newspaper than their 'news presence' (i.e. appearances), suggesting that migrants tend to be more often talked about than to. Very low levels of quotation were found in the Glasgow 'Bad News' study of refugee coverage in 2006 and 2011, where refugees/asylum seekers comprised only $3 \%$ of quotation in related news coverage (Philo et al., 2013b).

Crawley et al. suggest that there are three key reasons why the exclusion of migrant voices from public debate matters: audiences are deprived of a complex and nuanced understanding of migration (e.g. an emphasis on borders and numbers to the neglect of human consequences), this in turn fuels prejudice and animosity among the public and has a negative effect on the well-being of migrants themselves (2016). Khosravinik (2010) argues persuasively that this silencing of the subjects in this policy discourse is a by-product of the dominance of 'political rivalry' discourses noted earlier, in which immigration is constructed as an issue of policy, numbers and statistics. This objectifies and backgrounds the people about whom there is a debate and makes first-hand perspectives of migrants seem unimportant or irrelevant.

This is not to suggest that non-official sources are completely excluded from mainstream news coverage, and in this respect the ideological orientation of particular news organisations seems to be a contributory influence. For example, Threadgold (2009), van Dijk (1991) and Berry et al. (2015) separately note that experts, NGOs, and the voluntary sector are often prominent in the left-leaning press. More generally, several authors note how advocate sources which can be relied upon to produce reliable copy in line with a news outlet's typical line on immigration are more likely to gain a hearing (Balch \& Balabanova, 2010; Buchanan et al., 2003; van Dijk, 1991). Partisanship also seems to affect the extent to which migrants are featured and quoted. For example, Crawley et al. (2016) found that the left-of-centre Daily Mirror featured migrant voices in a third of their reports, compared with only $3 \%$ of stories in the Sun.

When migrants are called upon to voice their perspectives on matters affecting their lives, evidence suggests that their marginalisation from the debate is compounded by the often subverting consequences of their involvement. Baker et al. 
(2008) suggest, for instance, that quotation patterns in the right-wing press indicate that 'citation to out-group members is provided when they are (or can be represented as being) inarticulate, extremist, illogical, aggressive or threatening' (pp. 294-295). Similarly, Threadgold suggests that 'if and when migrants are used as sources, their voices tend to be incorporated into the dominant story of policy that is out of control and failing to stop "hordes" of people from getting into Britain' (Threadgold, 2009, p. 11).

Several reasons have been suggested for the over-reliance on official sources. On the demand side, official sources may be seen as more 'objective and neutral' by some journalists (Bennett et al., 2013, p. 257, Buchanan et al., 2003; Hall et al., 1978; van Dijk, 1991). Others note the paucity of specialist journalists or migrant employees in newsrooms to help redress problematic reporting practices (Law, 2002; Gemi et al., 2013; Markova \& McKay, 2013; Statham, 2002). On the supply side, migrant advocacy groups often lack the resources and status of their 'official' counterparts (Bennett et al., 2013; van Dijk, 1996), migrants may lack the linguistic or other capabilities to provide journalists with timely and compelling quotations, and they may also fear the consequences of making a contribution, whether in the framing of the report or beyond (Crawley et al., 2016; Philo et al., 2013b).

\section{Conflating categories}

News coverage often fails to make adequate distinctions between the various types of migration and the categories associated with these types, instead conflating them together in a relatively undifferentiated way (Baker et al., 2008; Bennett et al., 2013; Blinder \& Allen, 2015; Buchanan et al., 2003; Gabrielatos \& Baker, 2008; Goodman \& Speer, 2007; Khosravinik, 2009; Berry et al., 2015; Philo et al., 2013a, 2013b; Smith, 2015).

The main ways in which conflation occurs are through the use of synonyms for conceptually distinct migration categories (e.g. referring to the same group of people as both immigrants and asylum seekers), through association (e.g. the colocation of issues relating to 'illegal' immigrants and asylum seekers in the same article) and the proliferation over time of neologisms that serve to blur the distinctions between categories (e.g. 'illegal asylum seeker', 'economic refugee') (Smith, 2015). 
Perhaps one of the most prominent examples of conflation in recent years has been the use of the terms 'bogus' and 'genuine' to refer to asylum seekers and refugees, particularly in the press. The use of these terms became more common through the 1990s (Kaye 1998, 2001; Smith, 2015) and continued into the 2000s (Buchanan et al., 2003; Gabrielatos \& Baker, 2008; Lynn \& Lea, 2004; Matthews \& Brown, 2012; Philo et al., 2013a), although some studies have found that the terms are used relatively infrequently (e.g. Gross et al., 2007). It is notable that the neologisms and subsequent rise in importance of distinctions between deserving ('genuine') and undeserving ('bogus') refugees/asylum seekers came during a period of intense political interest in deterring and criminalising asylum seekers from the early 1990 s to the early 2000 s in particular.

In the context of the politics of immigration, the conflation of migration types is important as evidence suggests that the public's (mis)perceptions about the scale, nature and distinctions between types of immigration align closely with the representations advanced by mass media outlets (Blinder \& Allen, 2015; Blinder, 2015). While public opinion about immigration varies depending on preferred attributes such as skill level, purpose of settlement, ethnicity, cultural proximity among others (Ford et al., 2012; Ford, 2011, Hainmueller \& Hopkins, 2014; KaurBallagan \& Mortimore, 2017; Naumann et al., 2018; Valentino et al., 2017), there are significant differences between 'imagined immigration' (i.e. how people perceive immigration) and 'statistical immigration' (i.e. government records of immigration). Consequently, if and when media representations do conflate groups of migrants and thereby fuel public misperceptions this could have a significant impact on the pressure that is brought to bear on government policy (Blinder, 2015). Subsequent public policy demands may, for instance, be based on spurious connections and elisions made between migrant groups of differing origins, international rights, number, degrees of agency, etc, and which may serve to undermine the case for appropriate legal distinctions to be made between them (Goodman \& Speer, 2007; Goodman et al., 2017). Moreover, targets to reduce overall immigration (as has been UK government policy throughout the 2010s) can ultimately lead to popular but populous groups becoming the target of greater restrictions, counter to a nuanced reading of public preferences (Blinder, 2015). 


\section{Concluding remarks}

This review of the corpus of more than forty years' research into UK media reporting of immigration and related issues demonstrates strong continuities in most areas identified, but also some developments and potential avenues of change. In terms of continuities, the research highlights persistent negativity and narrowness in the overall patterning of news discourses, for example in the consistent marginalisation of minority voices, the narrow interpretative framework of immigration coverage, and the dominance of pejorative lexical choices or those that serve to conflate distinct categories of migrants. The degree of apparent continuity and entrenchment in these features of coverage should be of concern to those who value an informed, detailed and reasoned debate and who assume some meaningful political consequences to media coverage.

But in noting these propensities, there is also a need to acknowledge countervailing tendencies within mainstream news coverage. This is not an entirely closed and unreflexive debate and a number of the studies cited above show that counter currents can be found in the left-of-centre broadsheets and tabloids, the broadcast media, as well as within the local (e.g. Finney \& Robinson, 2008; Machin \& Mayr, 2007) and diasporic (e.g. Nickels et al., 2012) media. It is also worth noting that even the most consistently hostile outlets occasionally feature episodically positive coverage, for instance by championing the causes of individual cases in typical tabloid campaigning style. Recent examples include the case of Alan Kurdi in 2015, which formed the basis for both highly sympathetic news coverage and viral social media discussion of its meaning for European society (Chouliaraki et al., 2015; Bennett, 2018; Vis \& Goriunova, 2015), and the 'Windrush' scandal of 2018, in which long-term residents of the UK who arrived several decades ago from Commonwealth countries became caught up in government policy to create a 'hostile environment' for irregular migrants. The coverage which marks these exceptions is not always entirely unproblematic or politically inconsequential, particularly as they seem to shape how migrant groups may move in or out of a defined 'community of value' depending on the circumstances of public narratives of immigration (Anderson, 2013). Such exceptions may thereby simply reflect and compound the inverse logic of more typical representational patterns (e.g. by portraying 'good migrants' as 'exceptions to the rule', the employment of 'humanitarian' frames that rely on a 
paternalistic logic, or the celebration of the 'genuine refugee' that presupposes a 'bogus refugee'). Yet they represent a departure from the typical structure of coverage and therefore bear important implications for understanding the mediation of migration in general and its development in the future.

There is also evidence of change over time in the representations of immigration and immigrants in the UK media (e.g. Smith, 2015; Statham, 2002). In the main, this has been in revealing the shifting intensity of the coverage of immigration issues. Other changes within media patterns are harder to spot retrospectively due to the cross-sectional nature of many studies and differences in research design. This has made cross-temporal comparisons difficult. Moreover, a proliferation of research on contemporary patterns often also emphasises what isn't known about earlier periods, particularly those before the advent of robust studies in this area in the 1970s. The continuation of research with a crosstemporal/longitudinal focus (e.g. Smith 2015; Benson, 2014; McLaren et al., 2017) and the utilisation of common methodological standards will help to inform our sensitivity to continuity and change across the trends identified in this article.

Considering other avenues of further research, a greater appreciation of how the 'hybrid media system' (Chadwick, 2017) operates in relation to the politics of immigration would help to further ground analyses in how media is consumed by audiences. The notion of a hybrid media system has rightly become an increasingly influential concept in the field of media studies to explain how modern political communication operates in relation to a holistic and complex media system. In other words, such an approach incorporates an appreciation for the influence of both legacy media and digital media, which far from being distinct and separate should be thought of as inter-connected and mutually dependent. Instead, research tends to be conducted in one or the other area, and rarely are 'both' considered in terms of their place in the broader media ecology. There are some obvious downsides to this tendency. On the one hand, a neglect of legacy media in favour of a rush to digital media fails to appreciate the enduring influence of the former in the public sphere and on the content and nascent logics of the latter. On the other hand, digital media cannot be dismissed as ephemeral or insignificant, and researchers should continue to explore the distinctive dynamics of digital media, particularly in terms of their affordances, participation, influence on opinion formation and so on. 
Finally, there is a rich vein of research in a number of countries exploring the relationships between the mediation of migration, politics and public opinion, which has provided evidence about how people think about migration, how politicians prioritize immigration on the policy agenda, and on the perceptions, behaviours and attitudes of migrants themselves (Allen et al., 2017). The British context is not entirely without these kinds of perspectives, but we know far more about its news content than we do about how that content helps to shape (or is shaped by) political realities. Given the particular combination of components in considering the overall conditions of immigration discourse in Britain (e.g. antipathetic public opinion, active legislative programme, hostile right-wing print media, strong public service broadcasting tradition, widespread diffusion of internet-enabled devices, etc), this would seem to be an area in which further work can be done. This exploratory work will necessarily rely on the comprehensive body of work on media content that this review has considered. The themes we have highlighted recur frequently and with notable continuity. They would therefore seem to provide obvious departure points for the research that can be done in further considering the media-public-policy nexus in British immigration debates. 


\section{References}

Allen, W. (2016). A Decade of Immigration in the British Press (Migration Observatory report). Oxford: COMPAS, University of Oxford. Retrieved from http://www.migrationobservatory.ox.ac.uk/resources/reports/decade-immigrationbritish-press/

Allen, W., \& Blinder, S. (2013). Migration in the news: Portrayals of immigrants, migrants, asylum seekers and refugees in national British newspapers, 2010 to 2012 (Migration Observatory report). Oxford: COMPAS, University of Oxford. Retrieved from https://www.compas.ox.ac.uk/2013/pr-2013-migration_media/

Allen, W., Blinder, S., \& McNeil, R. (2017). Media reporting of migrants and migration. In IOM, World Migration Report 2018. Geneva: IOM.

Anderson, B. (2013). Us and Them?: The Dangerous Politics of Immigration Control. Oxford: Oxford University Press.

Augoustinos, M., \& Every, D. (2007). The Language of "Race" and Prejudice: A

Discourse of Denial, Reason, and Liberal-Practical Politics. Journal of Language and Social Psychology, 26(2), 123-141. https://doi.org/10.1177/0261927X07300075

Bagley, C. (1973). Race Relations and the Press: An Empirical Analysis. Race, 15(1), 59-89. https://doi.org/10.1177/030639687301500104

Bailey, O. G., \& Harindranath, R. (2005). Racialised 'othering': the representation of asylum seekers in the news media. In S. Allan (Ed.), Journalism: Critical Issues (pp. 274-286). Maidenhead: Open University Press.

Baker, P., Gabrielatos, C., KhosraviNik, M., Krzyżanowski, M., McEnery, T., \& Wodak, R. (2008). A useful methodological synergy? Combining critical discourse analysis and corpus linguistics to examine discourses of refugees and asylum seekers in the UK 
press. Discourse \& Society, 19(3), 273-306.

https://doi.org/10.1177/0957926508088962

Baker, P., \& McEnery, T. (2005). A corpus-based approach to discourses of refugees and asylum seekers in UN and newspaper texts. Journal of Language and Politics, 4(2), 197-226. https://doi.org/10.1075/jlp.4.2.04bak

Balch, A., \& Balabanova, E. (2016). Ethics, Politics and Migration: Public Debates on the Free Movement of Romanians and Bulgarians in the UK, 2006-2013. Politics, 36(1), 19-35. https://doi.org/10.1111/1467-9256.12082

Banks, J. (2012). Unmasking Deviance: The Visual Construction of Asylum Seekers and Refugees in English National Newspapers. Critical Criminology, 20(3), 293-310. https://doi.org/10.1007/s10612-011-9144-x

Barker, M. (1981). The New Racism: Conservatives and the Ideology of the Tribe. London: Junction Books.

BBC (2017). BBC's global audience rises to $372 m$. Retrieved from http://www.bbc.co.uk/mediacentre/latestnews/2017/global-audience-measure Bennett, S. (2018). New "Crises," Old Habits: Online Interdiscursivity and Intertextuality in UK Migration Policy Discourses. Journal of Immigrant \& Refugee Studies, 16(1-2), 140-160. https://doi.org/10.1080/15562948.2016.1257753

Bennett, S., ter Wal, J., Lipiński, A., Fabiszak, M., \& Krzyżanowski, M. (2013). The Representation of Third-Country Nationals in European News Discourse. Journalism Practice, 7(3), 248-265. https://doi.org/10.1080/17512786.2012.740239

Benson, R. (2014). Shaping Immigration News: A French-American Comparison. Cambridge: Cambridge University Press.

Berkeley, R., Khan, O., \& Ambikaipaker, M. (2006). What's new about new immigrants in twenty-first century Britain? York: Joseph Rowntree Foundation. Retrieved from 
https://www.jrf.org.uk/report/whats-new-about-new-immigrants-twenty-first-centurybritain

Berry, M., Garcia-Blanco, I., \& Moore, K., (2015). Press Coverage of the Refugee and Migrant Crisis in the EU: A Content Analysis of Five European Countries. UNHCR. Retrieved from http://www.unhcr.org/56bb369c9.html

Blinder, S. (2015). Imagined Immigration: The Impact of Different Meanings of 'Immigrants' in Public Opinion and Policy Debates in Britain. Political Studies, 63(1), 80-100. https://doi.org/10.1111/1467-9248.12053

Blinder, S., \& Allen, W. (2015). Constructing Immigrants: Portrayals of Migrant Groups in British National Newspapers, 2010-2012. International Migration Review, 50(1), 340. https://doi.org/10.1111/imre.12206

Blinder, S., \& Allen, W. (2016). UK public opinion toward immigration: overall attitudes and levels of concern. Oxford: COMPAS, University of Oxford. Retrieved from http://www.migrationobservatory.ox.ac.uk/resources/briefings/uk-public-opiniontoward-immigration-overall-attitudes-and-level-of-concern/

Buchanan, S., Grillo, B., Threadgold, T., \& Wengraf, T. (2003). What's the Story? Results from Research Into Media Coverage of Refugees and Asylum Seekers in the UK. Article 19. Retrieved from https://www.article19.org/data/files/pdfs/publications/refugees-what-s-the-story-.pdf Buonfino, A. (2004). Between unity and plurality: the politicization and securitization of the discourse of immigration in Europe. New Political Science, 26(1), 23-49. https://doi.org/10.1080/0739314042000185111

Carvalho, J., Eatwell, R., \& Wunderlich, D. (2015). The Politicisation of Immigration in Britain. In W. van der Brug, G. D'Amato, J. Berkhout, \& D. Ruedin (Eds.), The Politicisation of Migration (pp. 159-178). London: Routledge. 
Caviedes, A. (2015). An Emerging 'European' News Portrayal of Immigration? Journal of Ethnic and Migration Studies, 41(6), 897-917.

https://doi.org/10.1080/1369183X.2014.1002199

Chadwick, A. (2017). The Hybrid Media System: Politics and Power (2 ${ }^{\text {nd }}$ edition). Oxford: Oxford University Press.

Charteris-Black, J. (2006). Britain as a container: immigration metaphors in the 2005 election campaign. Discourse \& Society, 17(5), 563-581.

https://doi.org/10.1177/0957926506066345

Chouliaraki, L., Georgiou, M., Zaborowski, R., \& Oomen, W. (2017). The European 'migration crisis' and the media. A cross-European press content analysis. London: LSE. Retrieved from http://www.Ise.ac.uk/media@Ise/research/Media-andMigration/Migration-and-media-report-FINAL-June17.pdf

Crawley, H., McMahon, S., \& Jones, K. (2016). Victims and Villains: Migrant voices in the British media. Coventry: Centre for Trust, Peace and Social Relations, Coventry University and Open Society Foundations. Retrieved from http://www.coventry.ac.uk/research/research-directories/researchnews/2016/victims-and-villains/

Critcher, C., Parker, M., \& Sondhi, R. (1977). Race in the Provincial Press: a case study of five West Midlands newspapers. In Ethnicity and the Media (pp. 25-192). Paris: UNESCO.

Deacon, D., \& Smith, D. (2017). The politics of containment: Immigration coverage in UK General Election news coverage (1992-2015). Journalism. https://doi.org/10.1177/1464884917715944

Duffy, B. (2014). Perceptions and reality: Ten things we should know about attitudes to immigration in the UK. The Political Quarterly, 85(3), 259-266. 
Esipova, N., Ray, J., \& Pugliese, A. (2017). How the World Views Migration. Geneva: International Organization for Migration.

Finney, N., \& Robinson, V. (2008). Local press, dispersal and community in the construction of asylum debates. Social \& Cultural Geography, 9(4), 397-413. https://doi.org/10.1080/14649360802077038

Ford, R. (2011). Acceptable and unacceptable immigrants: how opposition to immigration in Britain is affected by migrants' region of origin. Journal of Ethnic and Migration Studies, 37(7), 1017-1037.

Ford R., Morrell G., \& Heath A. (2012). "Fewer but better"? Public attitudes to immigration. In A. Park, E. Clery, J. Curtice, M. Phillips, \& D. Utting (eds.). British Social Attitudes: The 29th Report (pp. 26-44). London: NatCen Soc. Res. http://www.bsa.natcen.ac.uk/media/38852/bsa29_full_report.pdf

Fotopoulos, S., \& Kaimaklioti, M. (2016). Media discourse on the refugee crisis: on what have the Greek, German and British press focused? European View, 15(2), 265279. https://doi.org/10.1007/s12290-016-0407-5

Fox, J. E., Moroşanu, L., \& Szilassy, E. (2012). The Racialization of the New European Migration to the UK. Sociology, 46(4), 680-695. https://doi.org/10.1177/0038038511425558

Gabrielatos, C., \& Baker, P. (2008). Fleeing, Sneaking, Flooding: A Corpus Analysis of Discursive Constructions of Refugees and Asylum Seekers in the UK Press, 19962005. Journal of English Linguistics, 36(1), 5-38.

https://doi.org/10.1177/0075424207311247

Gemi, E., Ulasiuk, I., \& Triandafyllidou, A. (2013). Migrants and Media Newsmaking Practices. Journalism Practice, 7(3), 266-281. https://doi.org/10.1080/17512786.2012.740248 
Gerard, L. (2017). A year of immigration in the white-tops. Retrieved from http://www.subscribe2015.co.uk/whitetops-immigration.html

Goodman, S., Sirriyeh, A., \& McMahon, S. (2017). The evolving (re)categorisations of refugees throughout the "refugee/migrant crisis". Journal of Community \& Applied Social Psychology, 27(2), 105-114. https://doi.org/10.1002/casp.2302

Goodman, S., \& Speer, S. A. (2007). Category Use in the Construction of Asylum Seekers. Critical Discourse Studies, 4(2), 165-185.

https://doi.org/10.1080/17405900701464832

Goodwin, M., \& Milazzo, C. (2017). Taking back control? Investigating the role of immigration in the 2016 vote for Brexit. The British Journal of Politics and International Relations, 19(3), 450-464. https://doi.org/10.1177/1369148117710799 Gordon, P., \& Rosenberg, D. (1989). Daily Racism: The Press and Black People in Britain. London: Runnymede Trust.

Gross, B., Moore, K., \& Threadgold, T. R. (2007). Broadcast news coverage of asylum April to October 2006: Caught between human rights and public safety. Cardiff: Cardiff School of Journalism, Media and Cultural Studies Cardiff University. Retrieved from http://orca.cf.ac.uk/53007/1/BroadcastNewsCoverageofAsylum.pdf Hainmueller, J., \& Hopkins, D. J. (2014). Public Attitudes Toward Immigration. Annual Review of Political Science, 17(1), 225-249. https://doi.org/10.1146/annurev-polisci102512-194818

Hall, S. (1990). The Whites of Their Eyes: racist ideologies and the media. In M. Alvarado \& J. O. Thompson (Eds.), The Media Reader (pp. 7-23). London: BFI. Hall, S., Roberts, B., Clarke, J., Jefferson, T., \& Critcher, C. (1978). Policing the Crisis: Mugging, the State, and Law and Order. London: Macmillan. 
Hartmann, P., \& Husband, C. (1974). Racism and the Mass Media. London: DavisPoynter.

Hartmann, P., Husband, C., \& Clark, J. (1974). Race as news: A study of the handling of race in the British national press from 1963 to 1970. In Race As News (pp. 88-173). Paris: UNESCO.

Helbling, M. (2014). Framing Immigration in Western Europe. Journal of Ethnic and Migration Studies, 40(1), 21-41. https://doi.org/10.1080/1369183X.2013.830888 Innes, A. J. (2010). When the Threatened Become the Threat: The Construction of Asylum Seekers in British Media Narratives. International Relations, 24(4), 456-477. https://doi.org/10.1177/0047117810385882

Ipsos MORI (2014). Perceptions are not reality: Things the world gets wrong. Retrieved from https://www.ipsos.com/ipsos-mori/en-uk/perceptions-are-not-reality-thingsworld-gets-wrong Jacomella, G. (2010). Media and migrations: Press narrative and country politics in three European countries (Reuters Institute Fellowship Paper). Oxford: Reuters Institute for the Study of Journalism, University of Oxford. Retrieved from https://reutersinstitute.politics.ox.ac.uk/our-research/media-and-migrations Kaur-Ballagan, K., \& Mortimore, R. (2017). Half of public support more immigration by highly skilled workers. Retrieved from https://www.ipsos.com/ipsos-mori/en-uk/halfpublic-support-more-immigration-highly-skilled-workers

Kaye, R. (1998). Redefining the Refugee: The UK Media Portrayal of Asylum Seekers. In K. Khoser \& H. Lutz (Eds.), The New Migration in Europe: Social Constructions and Social Realities (pp. 65-77). London: Macmillan.

Kaye, R. (2001). Blaming the victim: an analysis of press representations of refugees and asylum seekers in the United Kingdom in the 1990s. In R. King \& N. Wood (Eds.), 
Media and migration: Constructions of Mobility and Difference (pp. 53-70). London: Routledge.

Khan, A. W. (2012). UK Media's Pathology of the Asylum Seeker \& the (mis)

Representation of Asylum as a Humanitarian Issue. eSharp, Special Issue: The 1951 UN Refugee Convention-60 Years On, 54-86.

KhosraviNik, M. (2009). The representation of refugees, asylum seekers and immigrants in British newspapers during the Balkan conflict (1999) and the British general election (2005). Discourse \& Society, 20(4), 477-498.

https://doi.org/10.1177/0957926509104024

KhosraviNik, M. (2010). The representation of refugees, asylum seekers and immigrants in British newspapers: A critical discourse analysis. Journal of Language and Politics, 9(1), 1-28. https://doi.org/10.1075/jlp.9.1.01kho KhosraviNik, M. (2014). Immigration Discourses and Critical Discourse Analysis:

Dynamics of World Events and Immigration Representations in the British Press. In C. Hart \& P. Cap (Eds.), Contemporary Critical Discourse Studies (pp. 501-519). London and New York: Bloomsbury Academic.

Kilvington, D., \& Saeed, A. (2014). Inscriptions and depictions of 'race'. In M. Conboy \& J. Steel (Eds.), The Routledge Companion to British Media History (pp. 111-121). London: Routledge.

Law, I. (2001). Race in the News. Basingstoke: Palgrave.

Law, I. (2010). Racism and Ethnicity: Global Debates, Dilemmas, Directions. London: Pearson.

Lynn, N., \& Lea, S. (2003). 'A Phantom Menace and the New Apartheid': The Social Construction of Asylum-Seekers in the United Kingdom. Discourse \& Society, 14(4), 425-452. https://doi.org/10.1177/0957926503014004002 
Machin, D. \& Mayr, A. (2007). Antiracism in the British government's model regional newspaper: the 'talking cure'. Discourse \& Society, 18(4), 453-478.

Markova, E., \& McKay, S. (2013). Migrant Workers in Europe's Media. Journalism Practice, 7(3), 282-299. https://doi.org/10.1080/17512786.2012.740244

Matthews, J., \& Brown, A. R. (2012). Negatively shaping the asylum agenda? The representational strategy and impact of a tabloid news campaign. Journalism, 13(6), 802-817. https://doi.org/10.1177/1464884911431386

McAuliffe, M., Weeks, W., \& Koser, K. (2017). Media and migration: Comparative analysis of print and online media reporting on migrants and migration in selected countries. In M. McAuliffe \& K. Koser (Eds.), A Long Way to Go: Irregular Migration Patterns, Processes, Drivers and Decision-making (pp. 277-315). Canberra: ANU Press.

McLaren, L., Boomgaarden, H., \& Vliegenthart, R. (2017). News Coverage and Public Concern About Immigration in Britain. International Journal of Public Opinion Research. https://doi.org/10.1093/ijpor/edw033

McLaughlin, G. (1999). Refugees, migrants and the fall of the Berlin Wall. In G. Philo (Ed.), Message Received (pp. 197-209). Harlow: Longman.

Migrant Voice. (2014). Migration and the Media: The Impact of The Debate Perspectives and Voices of Migrants. London: Migrant Voice. Retrieved from https://www.scribd.com/document/261469750/Migration-and-the-media-The-impactof-the-debate-perspectives-and-voices-of-migrants

Mollard, C. (2001). Asylum: The truth behind the headlines. Oxford: Oxfam. Retrieved from http://policy-practice.oxfam.org.uk/publications/asylum-the-truth-behind-theheadlines-111959 
Moore, K., Gross, B., \& Threadgold, T. (2012). Migrations and the Media. Oxford: Peter Lang.

Musolff, A. (2015). Dehumanizing Metaphors in UK Immigrant Debates in Press and Online Media. Journal of Language Aggression and Conflict, 3(1): 41-56.

Naumann, E., F. Stoetzer, L., \& Pietrantuono, G. (2018). Attitudes towards highly skilled and low-skilled immigration in Europe: A survey experiment in 15 European countries. European Journal of Political Research. https://doi.org/10.1111/14756765.12264

Nickels, H. C., Thomas, L., Hickman, M. J., \& Silvestri, S. (2012). Constructing 'suspect' communities and Britishness: Mapping British press coverage of Irish and Muslim communities, 1974-2007. European Journal of Communication, 27(2), 135-151. https://doi.org/10.1177/0267323112445604

Philo, G., Briant, E., \& Donald, P. (2013a). The role of the press in the war on asylum. Race \& Class, 55(2), 28-41. https://doi.org/10.1177/0306396813497873 Philo, G., Briant, E., \& Donald, P. (2013b). Bad News for Refugees. London: Pluto. Picard, R., G. (2014). Public Opinion, Party Politics, Policy, and Immigration News in the UK (Working Paper). Oxford: Reuters Institute for the Study of Journalism, University of Oxford. Retrieved from https://reutersinstitute.politics.ox.ac.uk/our-research/publicopinion-party-politics-policy-and-immigration-news-united-kingdom

Polson, E., \& Kahle, S. (2010). Limits of National Discourse on a Transnational Phenomenon A Case Study of Immigration Framing in the BBC Online. International Communication Gazette, 72(3), 251-268.

https://doi.org/10.1177/1748048509356951

Searle, C. (1989). Your Daily Dose: Racism and the Sun. London: Campaign for Press \& Broadcasting Freedom. 
Semmelroggen, J. (2016). Britain's obsession with net migration makes it a global anomaly, The Conversation, 15 November. Retrieved from https://theconversation.com/britains-obsession-with-net-migration-makes-it-a-globalanomaly-67093

Smith, D. (2015). Immigration in UK newspapers during general election campaigns, 1918-2010. Loughborough University, Loughborough. Retrieved from https://dspace.Iboro.ac.uk/dspace-jspui/handle/2134/17997

Statham, P. (2002). United Kingdom. In Racism and cultural diversity in the mass media: an overview of research and examples of good practice in EU member states, 19952000 (pp. 395-420). Vienna: EUMC. Retrieved from http://fra.europa.eu/en/publication/2002/racism-and-cultural-diversity-mass-media Threadgold, T. (2009). The Media and Migration in the United Kingdom, 1999 to 2009. Washington, DC: Migration Policy Institute. Retrieved from http://www.migrationpolicy.org/research/media-and-migration-united-kingdom-19992009

Troyna, B. (1981). Public Awareness and the Media: A Study of Reporting on Race. London: Commission for Racial Equality.

Valentino, N. A., Soroka, S. N., lyengar, S., Aalberg, T., Duch, R., Fraile, M., Hahn, K. S., Hansen, K. M., Harell, A., Helbling, M., Jackman, S. D., \& Kobayashi, T. (2017). Economic and Cultural Drivers of Immigrant Support Worldwide, British Journal of Political Science, 1-26. DOI: 10.1017/S000712341700031X van Dijk, T. A. (1989). Race, riots and the press: An analysis of editorials in the British press about the 1985 disorders. International Communication Gazette, 43(3), 229253. https://doi.org/10.1177/001654928904300305 van Dijk, T. A. (1991). Racism and the Press. London: Routledge. 
van Dijk, T. A. (2000). New(s) Racism: A Discourse Analytical Approach. In S. Cottle (Ed.), Ethnic Minorities and the Media (pp. 33-49). Milton Keynes: Open University Press.

van Dijk, T. A. (2012). The Role of the Press in the Reproduction of Racism. In M. Messer, R. Schroeder, \& R. Wodak (Eds.), Migrations: Interdisciplinary Perspectives (pp. 15-29). Berlin: Springer.

Vicol, D.-O., \& Allen, W. (2014). Bulgarians and Romanians in the British National Press, 1 December 2012-1 December 2013. Oxford: COMPAS, University of Oxford. Retrieved from http://www.compas.ox.ac.uk/2014/pr-2014migration_media_bulgarians_romanians/

Vis, F., \& Goriunova, O. (2015). The Iconic Image on Social Media: A Rapid Research Response to the Death of Aylan Kurdi. Sheffield: Visual Social Media Lab, University of Sheffield. Retrieved from https://www.dropbox.com/s/hnydewwtido6nhv/VISSOCMEDLAB_AYLAN\%20KURDI \%20REPORT.pdf?dl=0

Vlandas, T. (2016). Xenophobia Britannica? Anti-immigrant attitudes in the UK are among the strongest in Europe, London School of Economics Blog. Retrieved from http://blogs.Ise.ac.uk/brexit/2016/10/21/xenophobia-britannica-anti-immigrantattitudes-in-the-uk-are-among-the-strongest-in-europe/

Wahl-Jorgensen, K., Sambrook, R. J., Berry, M., Moore, K., Bennett, L., Cable, J., Garcia-Blanco, I., Kidd, J., Dencik, L., \& Hintz, A. (2013). BBC Breadth of Opinion Review. Cardiff: Cardiff University, BBC. Retrieved from http://www.bbc.co.uk/bbctrust/our_work/editorial_standards/impartiality/breadth_opini on.html 
